\title{
China's Possible Role in Myanmar's National Reconciliation
}

\author{
ZOU KeYUAN
}

\begin{abstract}
China and Myanmar have maintained their good relations for centuries. Based on China's pragmatic foreign policy, China supports the current military regime in Myanmar through political, strategic, economic and cultural ties and exchanges. National reconciliation is a necessary step for Myanmar's future prosperity and security, including democratization in this country. Because of the good relationship between China and Myanmar and the former's strong influence, China has some role to play, albeit not a critical one, in Myanmar's national reconciliation. The limitation of China's role stems firstly from China's foreign policy (based on the Five Principles of Peaceful Co-existence) as well as from China's perception of democracy. On the other hand, China would like to see a stable and prosperous Myanmar close to its borders. This article examines these crucial issues and the ramifications for future co-operation.*
\end{abstract}

\section{Historical Link}

China and Myanmar are neighbouring countries and their contact with each other dates back to $122 \mathrm{AD}$ (Lin Xixing 1998: 4). Since that time, the Burmese had intermittent tributary relations with the Chinese empire, but this situation was severed by the invasion of the Western colonialists into the Asian region in the nineteenth century. After the founding of the People's Republic of China (PRC) in 1949, Sino-Myanmar relations were generally stable, except for the anti-Chinese riots which occurred in the late 1960s. The two countries established formal diplomatic relations on 8 June 1950. In the 1950s, China and Myanmar jointly initiated the Five Principles of Peaceful Co-existence, namely, mutual respect for territorial integrity and sovereignty, mutual non-aggression, non-interference in each other's internal affairs, equality and mutual benefit, and peaceful co-existence (Wang Tieya 1995: 58). ${ }^{1}$ In a spirit of mutual understanding and accommodation through friendly consultation, the two countries took the lead in working out a satisfactory solution to their 
border issues which had until then persisted as an unresolved historical legacy.

Leaders of China and Myanmar have a tradition of exchange visits. Many Chinese leaders of the older generation, including Chairman Liu Shaoqi, Premier Zhou Enlai and Vice-Premier Chen Yi, paid their respective visits while the Myanmar leaders, such as Chairman U Ne Win, President U San Yu and Prime Minister U Maung Maung Kha, reciprocally visited China on several occasions. Premier Zhou Enlai's nine visits to Myanmar and Chairman U Ne Win's twelve visits to China became a much-told tale between the two nations. Because of the traditional friendship, the two peoples always call each other 'Paukthaw', which means brother.

\section{China's Foreign Policy}

China's foreign policy has shifted several times since the founding of the PRC (see Garver 1993). The current policy is fundamentally based on the so-called Five Principles of Peaceful Co-Existence. These principles include: (1) mutual respect for each other's sovereignty and territorial integrity; (2) non-aggression; (3) non-interference in each other's internal affairs; (4) equality and mutual benefit; and (5) peaceful coexistence.

The Five Principles first appeared in the Agreement between the Republic of India and the People's Republic of China on Trade and Intercourse between Tibet Region of China and India signed on 29 April 1954 (United Nations Treaty Series 1958). Since then, the Five Principles have been reiterated in China's foreign policy documents as well as agreements, declarations and joint statements signed between China and other countries who are willing to adhere to these principles. According to one source, from 1954 to 1995, there were more than 150 of such documents (Wang Tieya 1995: 60). Thus in China's view, these principles have become the universally applicable principles among States, and thus the fundamental principles of international law.

While it is reasonable for China to point out that it created the Five Principles and by so doing contributed to the development of contemporary international law, yet we may argue that the Five Principles of Co-existence have been over-emphasized to some extent. If we compare the Five Principles with other established principles of international law, particularly those embodied in the UN Charter, we discover that only the fourth principle of 'equality and mutual benefit' contains some new elements because it combines equality with mutual benefit 
so as to emphasize the equality in economic relations. It is argued that the Five Principles bear little meaning in international law since they manifest only the existing basic principles of international law (Focsaneanu 1956: 177-78). In response, a Chinese authoritative scholar of international law justifies the Chinese approach by stating that:

1. the combination of five important principles in international law has formulated a systematic integration which constitutes the basis of international law;

2. the expression of mutual respect for sovereignty and territorial integrity emphasizes the concept of mutuality so as to manifest the principle that sovereignty is not absolute, but relative; and

3. the connection of equality to mutual benefit results in the combination of legal and economic equalities, thus equality becomes one of substance rather than merely theoretical (Wang Tieya 1995: 62; Wei Min 1985: 237-52; Shao Tienren 1985: 334-45).

It should be noted that the Five Principles have always been highly regarded in China, despite the changes that have occurred over time in the political and diplomatic environment since the foundation of the PRC.

China has pledged to pursue an independent foreign policy, which is designed to defend China's independence, state sovereignty and territorial integrity; create a favourable international environment for reform and opening-up to the outside world and for the modernization drive of the nation; and to maintain world peace and promote common development.

China vows not to establish a military bloc, join in the arms race or seek military expansion. ${ }^{2}$ China's previous experiences in joining the socialist bloc have left a bitter memory. China regards sovereignty as crucial for the formulation and existence of a nation-state. China has jealously defended its sovereignty because it is still a relatively weak country, though big, and because it was exploited blatantly by Western powers in the past (Chan 1999: 78-79). China claims that the main thrust of its foreign policy is to oppose hegemonism and to safeguard world peace. It holds that all countries are equal members of the international community whether they are big or small, strong or weak, rich or poor. All countries should settle their disputes and conflicts through peaceful consultations instead of resorting to force or the threat of force. No country should interfere in the internal affairs of another country under any pretext, still less bully the weak, invade or subvert other countries.

China holds that the diversity of the world should not be an obstacle to the development of relations between various countries but should serve as an impetus to mutual exchanges, complementarity and enrich- 
ment. All countries are entitled to choose their own social system, development strategies and lifestyle to suit their particular conditions. Each country's affairs should be decided upon by its own people. On this basis, China strongly opposes any form of intervention. China criticized NATO's intervention in Kosovo in 1999, stating that NATO's action was a violation of the principle of non-interference in the internal affairs of a sovereign country, and the principle of finding a peaceful solution to international disputes ( $\mathrm{Li}$ Bian 1999: 7). ${ }^{3}$ This attitude is also reflected in China's stance toward the Iraqi War launched by the American-British forces in March 2003. Since non-intervention is in China's eyes a fundamental principle in international relations, China itself has to abide by it. It is recalled that in Mao's era, China exported a 'communist revolution' to Southeast Asian countries. However, since the Deng Xiaoping reform era, China has adopted a more pragmatic diplomacy and no longer provides support for armed rebellion by Communist Parties.

Instead, China has enhanced its neighbourly relations with its surrounding countries as an important component of its foreign policy. China has set up or resumed normal relations with all the surrounding countries and settled the questions left over by history with most of the neighboring countries. Strengthening China's solidarity and co-operation with the developing countries is the basic framework of its foreign policy. China shares common historical experiences with the developing countries and is confronted with the same goal of safeguarding national independence and developing the economy. ${ }^{4}$

China no longer regards the Association of Southeast Asian Nations (ASEAN) as a 'jackal' of the imperialist West. Recently China's own economic reform brought it closer to its neighbouring countries in terms of interdependent and co-operative development. As commented, China's policy within Southeast Asia has become largely governed by a rational ordering of national priorities in the interdependence context of economic interests and continuing tensions with the United States and Japan (Leifer 1997: 168). The Southeast Asian region seems to be China's backyard and is therefore critical to its vital interests and strategic security. 'Stabilizing the surrounding areas' (wending zhoubian) is one of the top priorities in China's current foreign policy. Recently China further appeased the ASEAN countries by jointly signing agreements on economic co-operation and integration and, remarkably, the Declaration on the Conduct of Parties in the South China Sea in November 2002. ${ }^{5}$

In addition, China takes part in multilateral diplomatic activities. The Chinese government has realized the importance of human rights and 
acceded to 17 international human rights conventions. China signed the International Covenant on Economic, Social and Cultural Rights and the International Covenant on Civil and Political Rights in October 1997 and in October 1998 respectively, and ratified the first one in February 2001. However, China attaches more importance to economic rather than political and other rights, and views basic human rights as a possible trigger to social unrest in China. That is why China has so far not yet ratified the International Covenant on Civil and Political Rights.

\section{Current Sino-Myanmar Relations}

Over a long period of time, the bilateral relations between China and Myanmar have witnessed a stable development as both sides adhere to good-neighbourly friendship and pursue a path of co-operation in both international and regional affairs. In June 1999 when Secretary-1 of the State Peace and Development Council (SPDC) Lt-Gen Khin Nyunt visited China, leaders of both sides reached consensus on working towards a sustainable, stable, good-neighbourly and co-operative relationship oriented towards the twenty-first century. They also exchanged views in depth on further strengthening economic and trade co-operation between the two countries. Since then the bilateral relations have achieved a positive momentum of development. ${ }^{6}$

Over the years, the two countries have continued an exchange of highlevel visits. This is attested by the visits to Myanmar of State Councillor and Secretary-General of the State Council Luo Gan (in January 1991), State Councillor and Foreign Minister Qian Qichen (in February 1993), Premier Li Peng (in December 1994), Chairman Li Ruihuan (in March 1997) and Vice-Premier Wu Bangguo (in October 1997). The Myanmar leaders, including Chairman of the State Law and Peace Restoration Council Saw Maung (in August 1991), Secretary-1 of SPDC Khin Nyunt (in September 1994 and June 1999), Deputy Secretary-2 of SPDC Tin Oo (in November 1994), Chairman of the SPDC Senior General Than Shwe (in January 1996) and Vice Chairman of the SPDC General Maung Aye (in October 1996) paid their respective visits to China. President Jiang Zemin met with Chairman Than Shwe in Kuala Lumpur, Malaysia, in late 1997. Sound co-operation has been maintained between the Foreign Ministries of both countries. Diplomatic consultations at the viceministerial level have been held three times since the diplomatic consultation system was established in 1992. In January 1998, when Vice Foreign Minister Tang Jiaxuan visited Myanmar for diplomatic consultation, the two sides signed the Agreement on Mutual Exemption of Visa for 
Diplomatic and Service Passport Owners. In 1993, both sides agreed to reopen their Consulates-General: consequently the Myanmar ConsulateGeneral in Kunming and Chinese Consulate-General in Mandalay reopened in September 1993 and August 1994 respectively.

Stable military ties are maintained between the armed forces of both countries. In recent years, military leaders on both sides have sustained a momentum of exchange visits. Deputy Chief of General Staff He Qizong (in November 1991), Defence Minister Chi Haotian (in 1995), Chairman of the Military Commission of CPC Central Committee Zhang Wannian (in April 1996), and Chief of General Staff Fu Quanyou (in April 2001) paid their respective visits to Myanmar. Lt-Gen Than Shwe (in October 1989), Chief of the Army Lt-Gen Tin Oo (in December 1989 and November 1994) and Deputy Commander-in-Chief Senior General Maung Aye (in October 1996) visited China one after another.

In the areas of economic and technological co-operation and trade relations between China and Myanmar, there has been steady progress since the establishment of diplomatic relations. The first trade agreement between the two countries was signed in 1954. A new trade agreement signed in 1971 stipulated that each side should award 'most-favoured nation' status to the other side. Since December 1988, when the two countries started border trade, the annual bilateral trade volume increased by a wide margin, rising from US\$ 40 million to US\$ 760 million in 1995. In 1997-98, the bilateral trade volume decreased, owing to the impact of the Asian financial crisis, dropping to US\$ 640 million and US\$ 580 million in 1997 and 1998 respectively. The 2000 figure shows that the trade between the two countries reached US $\$ 620$ million (Yazhou Zhoukan 2001: 17). China's main exports to Myanmar include textiles, chemical raw materials, instruments and meters, machinery, medicines, etc. while the main imports from Myanmar include timber, local products, jade, livestock products, etc. China has aided in constructing 22 joint projects including the Yangon-Thanlyin Bridge, a sugar-processing plant, a textile factory, a plywood factory, a rice mill, a coal-fired powerplant, a gymnasium, theatre, etc. By the end of 1997, there had been 183 contracts for labour services and construction projects signed by Chinese companies in Myanmar and the total contract value reached US\$ 398 million. In 1998, 103 more contracts were signed and the contract value totalled US $\$ 523$ million. It has been reported that up to 2,000 Chinese companies have cumulatively invested US\$ 31.55 million in Myanmar (Yazhou Zhoukan 2001: 17).

Since the State Law and Order Restoration Council (SLORC), newly renamed the State Peace and Development Council (SPDC), came to 
power in 1988, Myanmar has played the 'China card'. According to one commentator, the military junta in Rangoon actually abandoned the non-alignment policy and cultivated close ties with China. Thus by the mid-1990s, Myanmar 'seemed to be drawn increasingly into a Chinese sphere of influence' (Seekins 1997: 525). Myanmar began its open economic policy after 1988, practising the reform path China had embarked upon in the late 1970s. The Myanmar leaders shared the same view as the Chinese leaders that an open economy could enhance the country's stability and increase the nation's economic strength (Lin Xixing 1999b: 28). The pro-China policy resulted in a number of significant benefits for the Rangoon regime. First, China helped the Myanmar government to stabilize the internal situation and to consolidate the power of the military junta. After the SLORC came to power, particularly after its refusal to accept the results of the 1990 general election, Myanmar faced hard economic sanctions from Western countries and international aid agencies. However, China provided substantial support. In addition, China stopped supporting the Myanmar Communist Party and persuaded the old Communist Party leaders to go to China for a comfortable retirement. ${ }^{8}$ Meanwhile, Myanmar adopted a flexible policy towards the ethnic and Communist rebels. Between March 1989 and May 1997, the military government signed peace agreements with 19 minority anti-government armed groups (Lin Xixing 2000: 27).

China helped Myanmar to strengthen its national defence and security through three means: (1) provision of advanced weapons; (2) assistance in building military installations; and (3) facilitating the peace dialogue between the military government and the anti-government armed groups through its own influence (Lin 1999b: 31). China has become the biggest provider of weapons for Myanmar (see Table 1). It should be pointed out here that the Burmese junta may turn these weapons against its own people. China's provision of armed might for the Burmese junta promoted the militarization process of the Burmese society (Seekins 1997: 539).

One significant event to attract attention on the world stage is China's assistance in establishing naval bases on Hianggyi Island in the Irrawaddy River Delta and in the Great Coco Island in the Indian Ocean, approximately 30 nautical miles from India's Andaman Islands.

Economically, the cross-border trade between China and Myanmar has expanded dramatically. The two countries concluded the Border Trade Agreement on 5 August 1988. According to statistics, trade increased to 2.569 billion and 3.084 billion RMB in 1993 and 1994 respec- 
TABLE 1: Arms Sales to Myanmar

\begin{tabular}{|l|c|c|c|c|}
\hline Weapon & Type & Units & Ordered & Delivered \\
\hline Fighter & F-7 & 4 & 1996 & 1998 \\
\hline Ground Attack & & 21 & 1996 & 1998 \\
\hline Trainer & K-8 & 4 & 1996 & 1998 \\
\cline { 3 - 5 } & Mod. Jianghu & 2 & 1994 & 1998 \\
\hline Frigate & Type-85 & 150 & 1991 & 1996 \\
\hline APC & Type-69 & 50 & 1993 & 1996 \\
\hline MBT & & 4 & 1998 \\
\hline
\end{tabular}

Key: APC: Armored Personel Carrier; MBT: Main Battle Tank.

Source: Adapted from Muni (2002:78).

tively (Lin 1999b: 30). In February 1996, Myanmar set up the MyanmarChina Economic Enhancement Committee to promote economic cooperation with China. An extreme view taken by one commentator is that 'the net consequence of the free border trade with China has been a Chinese takeover of Upper Burma' (Maung 1997: 520). Nevertheless, owing to the Asian financial crisis, the Sino-Burmese border trade met with some difficulties. For example, the trade in the border town Ruili, Yunnan, decreased from 110 million RMB in 1996 to 40 million RMB in 1997 (Lin 1999a: 14).

In the diplomatic arena, Myanmar, with the support of China, broke through the diplomatic blockade imposed by the West, particularly the United States. ASEAN decided to carry out a constructive engagement policy towards Myanmar and granted Myanmar ASEAN membership. Japan provided large loans to Rangoon. India tried to pull Myanmar into the sphere of the nascent association for Bangladesh-India-Sri Lanka-Thailand Economic Cooperation (BIST-EC) after it had witnessed China's growing influence in the Bay of Bengal (Guyot 1998: 191).

In short, China has helped Myanmar substantially, arguably to the extent that without China's help, the military regime in Rangoon could not have survived to date. 


\section{The ASEAN Mechanism}

ASEAN was formally established by the ASEAN Declaration in Bangkok on 8 August 1967. Its aims and purposes are, inter alia:

1. to accelerate the economic growth, social progress and cultural development in the region through joint endeavours in a spirit of equality and partnership;

2. to promote regional peace and stability through abiding respect for justice and the rule of law in the relationship among countries of the region and adherence to the principles of the United Nations Charter; and

3. to promote active collaboration and mutual assistance on matters of common interest in the economic, social, cultural, technical, scientific and administrative fields (Koh 1996: ii).

The ASEAN mechanism includes (1) an annual meeting of foreign ministers; (2) a standing committee under the chairmanship of the host country; (3) ad-hoc committees and permanent committees of specialists and officials on specific subjects; and (4) a national secretariat in each member country. In 1993, ASEAN countries agreed that ASEAN should consider the establishment of a regional human rights mechanism. They realized that the lack of an ASEAN mechanism allows the ASEAN countries few opportunities to take stock of human rights developments. The establishment of an ASEAN mechanism with government support could help to redress such an unfavourable situation, so that the ASEAN perspective would be better understood by outsiders. For this purpose, a working group for an ASEAN human rights mechanism formulated a policy initiative for the ASEAN governments in 1998. The Working Group made the following suggestions:

1. to promote and support human rights activities, in particular, those in commemoration of the $50^{\text {th }}$ anniversary of the Universal Declaration of Human Rights;

2. to regularize its contacts with the Working Group and acknowledge it as an important catalyst for the promotion of human rights in ASEAN, and to sustain the momentum for the eventual creation of a regional human rights commission; and

3. to create a task force to examine the issues of form, substance and procedure related to the establishment of a regional human rights commission; etc (Defensor Santiago 1999: 389).

Though the mechanism has not yet come into being, the human rights situation in Myanmar is no doubt within the common concern of the ASEAN member countries. Since Myanmar has joined ASEAN, it is obliged to enter into dialogues relating to human rights within the framework of ASEAN. 
On the other hand, ASEAN has established six basic principles to govern their relationships and resolve any differences. They include the mutual respect of (1) independence, (2) sovereignty, (3) territorial integrity, (4) national identity; (5) mutual non-intervention in internal affairs; and (6) resolution of differences and disputes through peaceful means (Yang Guanghai 1999: 66-70). By upholding these principles, other ASEAN countries agree not to interfere in the domestic affairs of Myanmar, although they are seeking to promote a dialogue between the military regime and the opposition forces. Unlike the approach taken by West and led by the United States, which applied sanction measures, the ASEAN members conducted a constructive engagement with Rangoon. Further, they admitted Myanmar's participation in ASEAN in 1997. In ASEAN's view, constructive engagement and support toward economic development do more to advance democracy and improve human rights conditions than can be achieved by an isolationist and retributionist approach (Seekins 1999: 17). ${ }^{11}$ Constructive engagement is also an avenue of influence. Aung San Suu Kyi's release from prison was viewed by ASEAN as a positive step both toward dialogue and reconciliation between the two adversaries as well as for the democratization of Myanmar, and an achievement of its constructive engagement policy (Mya Maung 1999: 272). ${ }^{12}$ Furthermore, ASEAN attempted to show its independence and the 'ASEAN way' of dealing with issues within this region. It would not subject itself to the pressure from the West led by the United States. In this respect, ASEAN's stance is quite similar to China's. The ASEAN role can also be seen in the appointment of the special UN envoy to Myanmar (for the bilateral dialogue between the UN and Rangoon on democracy and human rights), since this envoy is from Malaysia, an ASEAN member country.

\section{China's Possible Role}

Myanmar's national reconciliation is a necessary step towards democratization for this country. It has been at the heart of the democracy movement since 1988. There are two main components of the national reconciliation: (1) reconciliation between the military junta and the democratic forces led by Aung San Suu Kyi; and (2) reconciliation between Burmans and ethnic groups.

The ethnic reconciliation began in December 1990, when the Karen National Union agreed to the formation of the National Coalition Government of the Union of Burma (NCGUB) in Karen territory. Since then, several agreements have been concluded in this respect, including the 
1991 Manerplaw Agreement to establish a Federal Union of Burma; the 1997 Mae Tha Raw Hta Agreement regarding ceasefire and work with democracy movement; and the 1998 Toemwe Khaloe Agreement regarding ethnic and pro-democracy groups agreeing to work together to restore democracy and establish a federal system of government.

However, a stalemate has been reached in the dialogue between the pro-democratic forces and the military government, despite the call from the United Nations for tripartite dialogue to resolve Myanmar's future. ${ }^{13}$ The secret talks between the two sides since October 2000 have failed to produce any fruitful results. In order to push forward the democratic process in Myanmar, the pro-democratic groups supported by some foreign funds launched the National Reconciliation Programme in May $1999,{ }^{14}$ but so far there have been no substantial achievements. It should be realized that without the endorsement of the government, such a programme can hardly be implemented in practice. On the other hand, the recent secret talks between the military junta and the NLD annoyed the ethnic groups. They regarded such a dialogue 'as a meeting between two factions of Burmans' to redistribute the state power (Wain 2001: 6). They fear that their interest and rights might be compromised by such a secret dialogue without their participation. Thus, national reconciliation would be out of question without the involvement of the ethnic minorities.

National reconciliation, in China's eyes, is purely a matter of domestic affairs in Myanmar. To adhere to the principle of non-intervention in state-to-state relations, China will not express any view about how the Myanmar regime should launch a dialogue with the opposition forces. China should not and will not have the right to interfere. This is China's basic position.

China has shared the same view as Myanmar with regard to bilateral relations, international situations, human rights and Western values. They were both invaded and exploited by Western colonialists and are highly averse to the Western ideology. Both countries strongly oppose any interference in the domestic affairs of other countries on the pretext of religion or human rights. They have supported each other in the meetings of the UN Commission on Human Rights. China strongly protested NATO's military intervention in Kosovo, regarding it as a grave violation of international law and a source of human disaster. China thus will not be happy to see any country interfere in Myanmar's domestic affairs. However, on the other hand, China acknowledged the positive result of dialogues on human rights issues. China itself has 
such regular dialogues with the United States and the European Union. On 20 November 2000, China signed a memorandum of understanding with the Office of the UN High Commissioner for Human Rights to strengthen co-operation on human rights protection. Vice-Primer Qian Qichen reiterated China's consistent willingness to participate in international co-operation in this field and stressed that the dialogue was the only way to solve disputes relating to human rights issues (China Daily, 21 November 2000). For this reason, China will not oppose Rangoon's dialogue with any other countries regarding the human rights issues in Myanmar. Likewise, China will hold the same attitude towards the dialogue between the military regime and the opposition forces in Myanmar.

China's view about Aung San Suu Kyi is likely to be quite similar to the position it holds on the military junta in Rangoon. China usually regards the Nobel Prizes in Peace and/or Literature as political instruments of the West to humiliate or insult the countries that the West does not like. Hence those prizes, once given, contain subversive elements. This has been well illustrated by the Chinese negative attitude towards the Peace Prize given to Dalai Lama in 1989 and the Literature Prize awarded to Gao Xingjian in 2000 respectively. Second, China does not regard Aung San Suu Kyi as a potential minlawn (contender to the throne) in Myanmar. In the view of one Chinese scholar, Aung San Suu Kyi does not command sufficient talents to accomplish her aims and would be incapable of becoming the next leader of Myanmar. In her struggle, she faces not a few military leaders, but a strong, well-organized, unified and experienced Myanmar army, which cannot be easily overthrown (Mu 1997: 20). For that reason, China is very reluctant to push forward the dialogue of reconciliation between the Rangoon government and Aung San Suu Kyi. ${ }^{15}$ However, on the other hand, it should be noted that for the sake of the regional stability as well as for the interest of China in Myanmar, China does not like to see any domestic turmoil within that country. A friendly and stable Myanmar is very important for China. For that reason, China was the first to offer its congratulations to the National League for Democracy immediately after the 1990 general elections (Yawnghwe 2000: 80).

If the military junta is willing to arrive at a compromise with the opposition forces, China will be only too glad to see such an occurrence, and will possibly provide some kind of assistance upon the request of the Myanmar government. As reported, the military government has been actively seeking advice from China and Vietnam on how 
to refashion itself into a more acceptable form (Clark 1999: 787). The success of economic reform in China has encouraged the Rangoon regime to begin its own reform in recent years, and the China model may be regarded by Rangoon as the most suitable for the economic reform in Myanmar, which can develop economy on the one hand, while maintaining authoritarian control on the other.

Furthermore, since China is a regional big power, its influence over the surrounding countries is inevitable and natural. In addition, because of the good relationship between China and Myanmar, if China expresses its willingness to see the national reconciliation in Myanmar, the Myanmar government would be more likely to listen to China rather than yielding to pressures from other countries, particularly some Western hardliners.

There are other issues for China to consider. First, with regard to democratization, China faces the same problem. China would think of the possible impact from Myanmar on its own democratic process. At the present stage, China suppresses all the democratic movements, and political dissidents can only operate outside China. There is no such person as Aung San Suu Kyi within the Chinese territory. The tolerance of Aung San Suu Kyi and the National League for Democracy (NLD) in Myanmar may indicate the mercy of the military junta. In May 2002, Aung San Suu Kyi was released from home arrest and was allowed to visit places beyond the capital city of Myanmar, though harassment from the government occurs from time to time. In this sense, Myanmar is more democratic than China. On the other hand, whether Myanmar becomes democratic or not is purely a domestic matter of that country. According to China's pragmatic foreign policy, China will have to respect the choice of the Myanmar people.

Second, if there is a mechanism to be established within ASEAN in dealing with the issue of Myanmar, China will no doubt be willing to participate in the relevant process, as illustrated in the current ASEAN+3 and ASEAN+1 dialogues. China's attitude could be more supportive. Since the 1990s, the Sino-ASEAN relations have developed on a sound track with increasingly close political ties. The year 1995 saw the establishment of Senior Official Political Consultation mechanism, through which both China and ASEAN engage in talks regarding political and security issues every year. In July 1996, the status of China as a consultative dialogue partner of ASEAN was elevated to that of a full dialogue partner, the ASEAN Committee of Beijing (ACB) was established by the ASEAN Heads of Missions in Beijing (Song 2000: 28). In Decem- 
ber 1997, President Jiang Zemin and ASEAN leaders held their first ever summit and issued a joint statement, in which they announced their decision to establish a twenty-first century oriented partnership of good neighbourliness and mutual trust between China and ASEAN. In February 1997, the ASEAN-China Joint Cooperation Committee (ACJCC) was formed and it was agreed that a round-table dialogue be established, to consist of five parallel mechanisms as follows:

- China-ASEAN Senior Officials Political Consultations,

- China-ASEAN Joint Committee on Economic and Trade Cooperation,

- China-ASEAN Joint Committee on Science and Technology,

- China-ASEAN Joint Co-operation Committee and

- ASEAN Committee in Beijing (ACB).

In addition, China and ASEAN have signed the framework agreement on mutual co-operation. As a result, China has enhanced mutual understanding and trust with ASEAN in the political and security fields. The close tie between China and ASEAN may well indicate that China would prefer a dialogue regarding Myanmar within the framework of ASEAN. It is obvious that China has a stake in ASEAN. If the Myanmar issue damages the relationship between/among the ASEAN members, it will also damage Sino-ASEAN relations.

Third, the 'China card' is no doubt important for the Rangoon regime. It has brought many benefits vis-à-vis the relations with the United States and ASEAN countries, particularly Thailand (Lin 1999b: 32). However, as stated by some scholars, Rangoon has now realized that it is placing too much reliance on China for political, military and economic support. To maintain its independence and diplomatic strategy, it has balanced the Chinese influence by using the 'ASEAN card' and the 'West card', particularly the Japanese card. Since the accession to ASEAN and the Asian financial crisis, China's influence in Myanmar has declined. At some point Rangoon may seek to balance reliance on China by improving ties with India (Garver 2001: 274). It is obvious that increased contacts with other members of the world community, will lessen the dependence of the Rangoon regime on China's support. Myanmar may choose to return to U Nu's old foreign policy of strict neutrality and non-alignment. In 1999, foreign observers reported a cooling of BeijingRangoon ties (see Davis 1999: 30-34). For this reason, China's role in Myanmar's national reconciliation is limited, though China's influence in other areas is immense. 


\section{Prospects}

The military junta in Rangoon still faces pressures from both inside and outside the country. Domestically, the opposition forces will continue to voice their demands for democracy in Myanmar. The minority armed rebels, despite having signed truce agreements with the government, may step up their demands. However, the most pressing matter is how to transfer the state power from the military junta to a civilian government. As promised by the military government in 1990, once the new constitution had been formulated and the state order had been restored, then the power should be handed over to a civilian government. The developments in the 1990s showed that the military government was very reluctant to make such a handover. The demise of the Suharto regime in Indonesia may have dealt a heavy psychological blow to the Rangoon military regime because the latter had tried to follow the Indonesian model for its survival as well as development (Seekins 1999: 18). ${ }^{16}$ The military junta has to consider other alternatives. Hence, the domestic situation in Myanmar remains tense and uncertain unless a national reconciliation takes place as soon as possible.

The external pressure is at present largely coming from the United States. It has maintained its economic sanctions against Myanmar, though whether the sanctions could play a critical role is unknown. The available data indicate that to date such a hardline approach has not been been effective in pushing the Myanmar government to change its policy (Clark 1999: 783). Despite this, it is still a pressure tormenting the Rangoon regime. Pressures may also come from other ASEAN member countries. In 1998, Thailand and the Philippines openly criticized Myanmar's violation of human rights (Li Bian 1999: 17).

As to China, it will continue its firm support of Myanmar. China criticized the United States' 'hegemonistic behaviour' when it declared its second economic sanctions against Myanmar in April 1997 (Zuo et al. 1997: 18). On the other hand, China was concerned about whether Myanmar would yield to the American pressure. It is suggested that China should continue to reinforce its economic and trade co-operation with Myanmar, to promote the friendly relationship between ASEAN and Myanmar, and to support the Myanmar government, particularly in the human rights field (Zuo et al. 1997: 19). Economic co-operation can increase China's stake in Myanmar. As the Commercial Councillor at the Chinese Embassy to Myanmar admitted, the investment in Myanmar is not purely based on commercial interests, but rather on 
political considerations (Yazhou Zhoukan 2001: 17). No doubt China will continue to maintain the traditional friendly relationship with Myanmar.

From the Myanmar side, the close political, military and economic ties with China are a major source of comfort to the SPDC, particularly when it faced sanctions and isolation from the West. 'They are a critical factor in the government's belief that, in a worst case scenario, it would be able to survive, and indeed prosper, on the basis of its bilateral activities with that nation' (Clark 1999: 786). One thing is clear: if the United States and possibly other countries continue to impose sanctions against Myanmar, this country will continue to choose to rely heavily on China. While we have seen the close relationship between the two countries, we should be aware that problems and issues exist in their relationship. It is reported that many Burmese view the Chinese 'as a new crop of colonists' (Roy 1998: 174). One commentator has predicted that 'local resentment of immigrant Chinese is potentially a serious problem, and it could lead to a replay of the anti-Chinese riots of 1967' (Seekins 1997: 530). That author even concluded negatively that the Rangoon regime was playing with fire in having such close ties with China (ibid.: 539). ${ }^{17}$

While it might be argued whether these negative conclusions are well founded, it has to be admitted that potential problems and issues exist. Their resolution will depend on the wisdom and actions of the two countries. On the other hand, the Sino-Myanmar relations will continue to develop. A plan for a 'Golden Quadrangle' encompassing Yunnan Province of China, Upper Burma, northern Thailand and Laos has been discussed by these four countries (Yang Xiaohui 1999: 25-30, 35). If this plan comes to fruition, it will no doubt enhance the economic development of the region as well as the co-operation among the countries concerned. It should be noted that no matter who is in power, the SinoMyanmar relationship will be maintained and developed in a friendly and stable manner, as manifested by their historical transactions.

National reconciliation is necessary for Myanmar and dialogue is the only avenue of hope and success. We have to wait and see whether the military junta is willing to sit together with the NLD members and Aung San Suu Kyi as well as ethnic groups to build a democratic society in Myanmar. It may yet take some time to reach this goal.

Zou Keyuan is Senior Research Fellow, East Asian Institute, National University of Singapore. 


\section{NOTES}

* The author is grateful to two anonymous referees for their helpful comments and suggestions on the previous version of this article. However, the author assumes the sole responsibility for any error or omission.

1 They were contained in theSino-Burmese Joint Declaration dated 29 June 1954, and adopted as guidelines of the bilateral relations between the two countries (Wang Tieya 1995: 58)

2 See http:/ /www.fmprc.gov.cn (accessed: 18 November 2000).

3 The NATO intervention is regarded as an analogy of the Aggression of the Eight Powers Alliance against China in the late 1800s (see Ma Yuezheng 1999: 5).

4 See http://www.fmprc.gov.cn (accessed: 18 November 2000).

5 Texts are available in http:/ / www.aseansec.org/13495.htm (accessed: 7 April 2002).

6 See http://www.fmprc.gov.cn (accessed: 18 November 2000).

7 Ibid.

8 It is noted that China stopped its 'export of revolution' to Southeast Asia after 1978 except for the Burma Communist Party (to about 1988) and the Khmer Rouge (to 1991) (Hinton 1994: 352).

9 The ASEAN Declaration, 8 August 1967, reprinted in Koh (1996: ii).

10 Working Group for an ASEAN Human Rights Mechanism, 'Synopsis of a Policy Initiative for the Establishment of an ASEAN Human Rights Mechanism', reprinted in Defensor Santiago (1999: 389).

11 Thai Foreign Minister Surin Pitsuwan once proposed the concept of 'flexible engagement', a franker, more critical discussion of the internal problems of member states which challenged ASEAN's 30 year-old policy of strict non-interference.'Flexible engagement' was rejected by a majority of foreign ministers attending the July 1998 ASEAN Summit in Manila, though Surin was supported by the host country's foreign minister, Domingo Siazon (Seekins 1999: 17)

12 However, Mya Maung denied any positive effect resulting from the constructive engagement policy by stating that 'a constructive engagement policy can only lead to a prolongation of the military's stranglehold on power to the detriment, in this case, of the democracy movement led by Daw Suu Kyi and the NLD' (Maung 1999: 285).

13 The United Nations urges the government of Myanmar to take urgent and meaningful measures to ensure the establishment of democracy in accordance with the will of the people as expressed in the democratic elections held in 1990 and to engage immediately and unconditionally in a genuine and substantive dialogue with the leaders of political parties and of ethnic minorities with the aim of achieving national reconciliation and the restoration of democracy. See UN DOC. E/CN.4/RES/2000/23 (Situation of Human Rights in Myanmar), 18 April 2000.

14 National Reconciliation Program (revised November 1999), kindly provided by Mr. Harn Yawnghwe, Director of the European Office for the Development of Democracy in Burma, Brussels.

15 It should be noted that China has never openly criticized Aung San Suu Kyi, and the latter has never done that either, though she once complained aboutChina's support of the Rangoon regime. It seems that both sides maintain some degree of flexibility for future dialogue.

16 As is pointed out, Soeharto's resignation in May 1998 may have exposed the bankruptcy of the 'Indonesian model' of army-directed state building, which the National Convention incorporated into its new constitution (Seekins 1999: 18).

17 He listed three reasons: First, abandonment of Burma's traditional neutrality may draw the country into conflicts between China and other Asian countries by the beginning of the next century. Second, Chinese involvement in, and even domination of the domestic economy, especially in Upper Burma, may spark communal violence similar to the anti-Chinese riots 
of 1967, or mob attacks on Burmese Muslims in 1997. Third, China's large-scale contributions to SLORC's armed force, in the form of weapons, infrastructure aid, and training, might promote the ongoing militarization of Burmese society, which will only lead to more violence and instability as the generals turn away from non-violent alternatives that alone can bring the country social peace and development (Seekins 1997: 539).

\section{REFERENCES}

Chan, Gerald 1999. Chinese Perspectives on International Relations: A Frameworkfor Analysis. London: Macmillan.

Clark, Allen L. 1999. 'Myanmar's Present Development and Future Options.' Asian Survey 39 (5): 772-91.

Davis, Antony 1999. 'China's Shadow.' Asiaweek, 28 May: 30-34.

Defensor Santiago, Miriam 1999. International Law with Philippine Cases and Materials and ASEAN Instruments. Quezon City, Philippines: Central Professional Books.

Focsaneanu, Lazar 1956. 'Les cinq principes de coexistence et le droit international.' Annuaire français de droit international. Paris, L'Université Panthéon-Assas (Paris II): $170 \mathrm{ff}$.

Garver, John W. 1993. Foreign Relations of the People's Republic of China. New Jersey: PrenticeHall.

- 2001. Protracted Contest: Sino-Indian Rivalry in the Twentieth Century. Seattle: University of Washington Press.

Guyot, James 1998. 'Burma in 1997: From Empire to ASEAN.' Asian Survey 38 (2): 190-95.

Hinton, Harold C. 1994. 'China as an Asian Power.' In Thomas W. Robinson and David Shambaugh (eds), Chinese Foreign Policy: Theory and Practice. Oxford: Clarendon Press.

'Human rights memorandum signed with UN' 2000. China Daily, 21 November.

Koh, K. L. (ed.) 1996. Selected ASEAN Documents on the Environment. Singapore: Asia-Pacific Centre for Environmental Law, National University of Singapore.

Leifer, Michael 1997. 'China in Southeast Asia: Interdependence and Accommodation.' In David S. G. Goodman and Gerald Segal (eds), China Rising: Nationalism and Interdependence. London: Routledge.

Li Bian 1999. 'NATO Challenges International Laws.' Beijing Review, April 26-May 2: 7.

LiChenyang 1999. 'Dongnanya jingrong weiji dui miandian yingxiang de fengxi' [An Analysis of the Impact of Southeast Asian Financial Crisis on Myanmar]. Dongnanya yanjiu [Southeast Asian Studies] 1.

Lin Xixing 1998. 'Zaoqi miandian huaren jingii shehui de xingcheng' [On the Formation of Burmese Overseas Chinese Economic Societies in the Early Time)]. Dongnanya yanjiu [Southeast Asian Studies)] 4.

— 1999a. 'Miandian sanshi dui dongmeng zai jingrong weiji zhong de qiwang' [Myanmar Loses Its Expectation on ASEAN in the Financial Crisis]. Dongnanya yanjiu [Southeast Asian Studies] 1.

— 1999b. 'Lengzha hou miandian de dui hua zhengze' [Myanmar's Policy toward China after the Cold War]. Dongnanya yanjiu [Southeast Asian Studies] 4.

- 2000. 'Miandian guonei zhengzhi he guoji guanxi xianzhuang' [The Present Situation of Myanmar's Internal Politics and International Relations]. Dongnanya yanjiu [Southeast Asian Studies] 3.

Ma Yuezheng 1999. 'Xingzhongguo de waijiao' [Diplomacy of the New China] Hebei shehui kexue [Hubei Social Sciences] 6.

Maung, Mya 1997. 'Burma's Economic Performance under Military Rule: An Assessment,' Asian Survey 37 (6): 503-24.

— 1999. 'The Burma Road to the Past.' Asian Survey 39 (2): 265. 
Mu Sheng 1997. 'An san su ji zai dangqian mian dian zhengzhi zhong de zuoyong' [Aung San Suu Kyi's Role in the Present Burmese Politics]. Dongnanya yanjiu [Southeast Asian Studies] 1.

Muni, S. D. 2002. China's Strategic Engagement with the New ASEAN: An Exploratory Study of China's Post-Cold War Political, Strategic and Economic Relations with Myanmar, Laos, Cambodia and Vietnam. Singapore: Institute of Defence and Strategic Studies, Nanyang Technological University.

Roy, Denny 1998. China's Foreign Relations. Lanham: Rowman \& Littlefield.

Seekins, Donald M. 1997. 'Burma-China Relations: Playing with Fire.' Asian Survey 37 (6): 525-39.

— 1999.'Burma in 1998: Little to Celebrate.' Asian Survey 39 (1): 12-19.

Shao Tienren 1985. 'Heping gongchu wuxiang yuanze-dangdai guojifa dejichu' [Five Principles of Peaceful Co-existence-Basis for Contemporary International Law]. Zhongguo guojifa niankan [Chinese Yearbook of International Law]: 334-45.

Song Dexing 2000. 'Zhongguo dongmeng guanxi de congxin dingwei jiqi zai siji jiaoti zhong de zhongyao tezheng' [Repositioning the Sino-ASEAN Relations and their Important Characteristics in the Transitional Period of Centuries]. Zhonghuo waijiao [China Diplomacy] 2.

UN DOC. E/CN.4/RES/2000/23 (Situation of Human Rights in Myanmar), 18 April 2000.

United Nations Treaty Series 1958. Vol. 299. New York: United Nations.

Wain, Barry 2001. 'Ethnic Conflict Clouds Myanmar.' Asian Wall Street Journal, 20 April.

Wang Tieya (ed.) 1995. Guojifa [International Law]. Beijing: Law Press.

Wei Min 1985. 'Heping gongchu wuxiang yuanze zai dangdai guojifa zhong de yiyi' [Significance of the Five Principles of Peaceful Co-existence in Contemporary International Law]. Zhongguo guojifa niankan [Chinese Yearbook of International Law]: 237-52.

Yang Guanghai 1999. 'ASEAN's Intra-Dispute Management: Principles, Channel and Ways.' Dongnanya yanjiu [Southeast Asian Studies] 3: 66-70.

Yang Xiaohui 1999. 'An Analysis of the Quadrilateral Economic Co-operation Program of Mainland China, Laos, Myanmar and Thailand', Dongnanya yanjiu [Southeast Asian Studies] 2.

Yawnghwe, Harn 2000. 'EU-ASEAN Relations:ABurmese/Myanmar Perspective.' Panorama 2. Yazhou Zhoukan [Asian Weekly] 2001. 'Real Friends Help Each Other', 23-29 April.

Zuo Xiao'an et al. 1997. 'Meiguo dui mian zhicai dui dongnanya de yingxiang' [The Influence of American Sanctions against Myanmar on Southeast Asian Situation] Dongnanya yanjiu [Southeast Asian Studies] 4. 